\title{
A Study on the Perceptions of Secondary School Students regarding the Form-focused and Communication-focused English Instruction
}

\author{
Zhiwen Feng ${ }^{1}$ \\ ${ }^{1}$ School of Foreign Languages, Yunnan Normal University, Kunming, P.R. China \\ Correspondence: Zhiwen Feng, School of Foreign Languages, Yunnan Normal University, Kunming, Yunnan, P.R. \\ China. Tel: 86-138-8859-9089. E-mail: fengzhiwen1228@163.com
}

Received: August 13, 2013

Accepted: August 30, 2013

Online Published: September 4, 2013

doi:10.5430/elr.v2n2p43

URL: http://dx.doi.org/10.5430/elr.v2n2p43

\begin{abstract}
Form-focused instruction (FFI) and communication-focused instruction (CFI) are two different L2 or foreign language teaching approaches. In actual teaching practice, almost every EFL teacher has a preference for them so that these two instructional approaches dominate EFL classrooms to a great extent. This study, by using a self-designed questionnaire, attempts to examine student perceptions toward FFI and CFI. The subjects in this quantitative study were 300 ninth graders and 300 twelfth graders from two public urban schools. Findings from two-way MANOVA analysis revealed that: 1) Both ninth-grade and twelfth-grade students held highly positive perceptions toward CFI, but they were not very positive toward FFI. In contrast, ninth graders showed more positive perceptions toward FFI than twelfth graders. 2) Gender differences existed in student perceptions toward FFI. Male students were more positive toward FFI than female students. 3) Results showed that the two predictors FFI and CFI had certain correlations with the academic achievement of ninth-grade and twelfth-grade students. Based on the findings of this study, a few constructive conclusions are as follows: 1) EFL teachers are encouraged to apply the communicative approach in class to foster and develop secondary school students' communication skills. 2) Teaching grammar to junior high and male students is likely to achieve effective results. 3) EFL teachers need to take gender differences into account when they design English curriculum. 4) Both FFI and CFI can help students achieve academic success at school.
\end{abstract}

Keywords: Form-focused instruction, Communication-focused instruction, Student perceptions, Chinese students, Secondary schools

\section{Introduction}

In the history of teaching English as a foreign language in China, EFL teachers have been placing a high value on teaching grammar. Even today when the Communicative Language Teaching (CLT) and Task-based Language Teaching are gaining more and more popularity in China, grammar teaching still dominates English classes to some extent. Of course, more and more EFL classroom teachers manage to achieve a balance between form-focused and communication-focused instruction. However, one phenomenon existing in Chinese context is that very often it is classroom teachers that decide what and how to teach. Usually, students' attitudes and perceptions regarding English curriculum don't receive enough attention. As a result, there exists a mismatch or inconsistence between students' perceptions and teachers' preferences. Sometimes, classroom teachers do not really know whether students are interested in the teaching approaches and methods as well as lesson content.

The hypothesis of this study is that EFL students can achieve English proficiency more easily if English instruction is based on their perceptions. Some scholars advocate that the role of student perceptions is of great importance in language teaching practice (Griego-Jones, 1994; Horwitz, 1989; McCaslin \& Good, 1996; Norris-Holt, 2002; Savignon \& Wang, 2003; Tse, 2000; Walker, 1976). As EFL teachers understand more about students' attitudes and perceptions, they are in a better position to prepare and implement an EFL curriculum and to adopt appropriate teaching approaches which are learner-based (Nunan,1988; Richards \& Nunan,1990; Richards \& Lockhart, 1994). Furthermore, EFL teachers are in a better position to foresee potential inconsistence and mismatches between instructional approaches and students' needs and preferences so that they are well prepared to narrow the gaps to help students achieve expected learning outcomes. Nevertheless, much of existing research is on college students' perceptions regarding English instruction. Particularly, there exists little comparative research on the attitudes and perceptions of junior and senior high students as well as male and female students regarding English instruction. 
This study, therefore, was designed to examine secondary school students' perceptions toward two different instructional approaches through a self-designed questionnaire. In order to achieve this purpose, the following three research questions will be used to guide the study: 1) What are the perceptions of Chinese ninth-grade and twelfth-grade students as well as male and female students regarding FFI and CFI? 2) Do Chinese ninth-grade and twelfth-grade students as well as male and female students differ in the perceptions of FFI and CFI? 3) How well is students' English academic achievement predicted by the two variables of FFI and CFI?

\section{Literature Review}

\subsection{Form-focused Instruction}

Form-focused Instruction (FFI) is an approach to L2 or foreign language teaching. According to the study of Spada (1997), FFI can be defined as "any pedagogical effort which is used to draw the learners' attention to language form either implicitly or explicitly" (p.73). In recent years two main types of FFI have been discussed among linguistic scholars. One type is Focus on Form, where attending to grammatical rules is usually part of a communicative class activity. The other type is Focus on Forms, where discrete grammatical rules are taught in lessons independent of communication (Ellis, 2001; Laufer, 2006), as in PPP - presentation, practice, and production (Harmer, 2007). More recently, Spada and Lightbown (2008) have made the distinguishment between what they call integrated and isolated FFI. Based on their viewpoint, both "isolated and integrated FFI can include explicit feedback on error, metalinguistic terminology, the statement of rules and explanations" (p.187).

According to the definition by Ellis (2001), FFI refers to "any planned or incidental instructional activity that is intended to induce language learners to pay attention to linguistic form" (p.1). Although much FFI research has been within the domain of grammar, actually FFI also refers to all formal linguistic aspects: grammar, pronunciation, spelling, etc. It covers a broad range of activities which focus learners' attention on the formal aspects in L2. This instructional approach can be intentionally provided when L2 students confront communication problems. From the reviews of FFI studies by (Ellis, 1994; Larsen-Freeman \& Long, 1991; Long, 1983; Norris \& Ortega, 2000), one viewpoint is that FFI should be integrated in L2 or foreign language curricula that are primarily meaning-oriented. Another viewpoint is that at least to some extent there should be an interface between explicit and implicit knowledge. Grammar teaching should play a considerable role in L2 or foreign language programs. Currently, an issue of primary interest is how FFI can be adopted to promote input processing mechanisms.

\subsection{Communication-focused Instruction}

Communication-focused Instruction (CFI) or Communicative Language Teaching (CLT) is another effective language teaching approach. It was first proposed in England in the 1970s, placing an essential emphasis on communication in L2 teaching. Its fundamental goal is to develop learners' communicative ability in L2 through communication and interaction with others (Brown, 2006; Canale \& Swain, 1980). Therefore, since its emergence CLT has rapidly gained a widespread acceptance in the field of second language acquisition. Being endorsed as a revolutionary reaction against the traditional language teaching, CLT has produced a great influence on language teaching practice in both ESL and EFL environments.

Today, with the rapid development of economic globalization, a general goal of second/foreign language teaching is to help learners build up communicative competence. In other words, a language course should focus not only on "linguistic competence" as its goal, but also on "communicative competence" in general. Here, the important term "communicative competence" in CLT was coined by Hymes in 1966 in reaction to the notion of "linguistic competence" by Chomsky (1965). As Hymes (1972) observes:

“... a normal child acquires knowledge of sentences not only as grammatical, but also as appropriate. He or she acquires competence as to when to speak, when not, and as to what to talk about with whom, when, where, in what manner. In short, a child becomes able to accomplish a repertoire of speech acts, to take part in speech events, and to evaluate their accomplishment by others." (p. 277)

Therefore, "communicative competence" refers to one's ability to encode and decode messages and to negotiate meanings interpersonally within particular contexts. Savignon (2002) further argues that communicative competence would depend on the cooperation of all the participants involved. Communication or negotiation of meaning is the only key to successful language learning. Through much debate, a more comprehensive definition of "communicative competence" is that it consists of grammatical competence, discourse competence, sociolinguistic competence and strategic competence (Canale \& Swain,1980; Hymes, 1972).

According to a recent academic definition by Richards (2006), the concept of "communicative competence" includes four aspects of language knowledge: 1) A learner knows the ways of using language for different purposes and 
functions. 2) A learner has the ability to vary the ways of using language based on the setting and the participants. For example, the learner is familiar with when to use formal speech and when not to. He also understands the subtle differences in the use of written and spoken language. 3) A learner knows the ways of producing and understanding various types of texts. For example, the learner has a good knowledge of how to produce the texts of narratives, reports, interviews and conversations. 4) A learner knows how to keep communication going in spite of having limitations in his language knowledge. For example, the learner has the ability to employ various communication strategies when he has difficulty in expressing his ideas.

\subsection{Previous Studies on Chinese Students' Perceptions regarding English Instruction}

Since the importance of student perceptions received attention by more and more researchers, increasing empirical studies about Chinese students' perceptions toward English instruction began to emerge in this pedagogical area. In contemporary literature, one of the earliest studies was conducted by Yu, Liu and Littlewood (1995). Their sample was 355 secondary school students in Hong Kong, responding to a questionnaire consisting of three parts, one of which was about students' perceptions toward their English learning. The survey purpose was to have a better understanding of student perceptions regarding English learning experiences so that EFL teachers could adopt practical ways to improve students' English proficiency. Their findings showed that students viewed grammar exercises as the most useful activities for improving their English learning. One case study by Yang (1999) was to explore English learning experiences of two college Chinese students. The results indicated that two subjects had difficulty in listening and speaking. When it came to the teaching and learning of grammar, two subjects agreed that it was essential for language learning.

Ten years ago, Savignon and Wang (2003) conducted a significant study in Taiwan, which was very similar to the present study in some aspects. They employed a questionnaire to investigate Chinese students' attitudes and perceptions toward classroom practices, which were identified as FFI and CFI. The survey sample was made up of first-year university students, including 69 male and 105 female subjects. In their study, although the sample was university students, the authors attempted to examine the students' learning experiences in junior and senior high schools. Their questionnaire consisted of four sections: classroom English activities in junior and senior high schools; students' attitudes and perceptions toward the teaching of English in junior and senior high schools; students' beliefs about English learning. The results of their study revealed that EFL students had a preference for meaning-focused approach. Two surprising findings of their study were that both junior and senior high students held negative perceptions toward grammar-based English instruction and that they showed positive attitudes toward CFI. Recently, Yang (2012) conducted an empirical study, investigating college business students' attitudes toward communicative or oral activities. Findings indicated that the surveyed subjects held positive perceptions toward task-based language approach, a meaning-based one.

One common goal of the above mentioned surveys is to help EFL teachers learn from learners and then in such a research process EFL teachers become more effective in their instructional practices. In China, academic scholars and researchers do not tend to conduct educational studies to probe into EFL learners' inner world, that is, their attitudes and perceptions. As a result of this research tradition, many studies focused on the perspectives of EFL teachers. Yang (1999) claims that students' initiative and stream of thought have been largely ignored. Considering that Chinese secondary school students are the biggest body of English learners in the world, exploring their perceptions toward English instructional approaches has great significance. Also, this study will help improve EFL teaching practice. Every teacher can learn a lot from his students (Eken, 1999) because each student brings with him different educational experiences when he comes to school.

\section{Research Methods}

\subsection{Research Design}

The research method used in this study was descriptive and comparative along with a $2 \times 2$ factorial design with grade and gender as two independent variables and with FFI and CFI as two dependent variables. The relationship between the independent and dependent variables were fully examined.

\subsection{Subjects}

According to the research design of this study, the chosen subjects were 300 ninth graders and 300 twelfth graders from two urban public schools. Among the subjects, one half were male students and the other half were female students. Additionally, considering that student perceptions change with age and education, this study randomly selected ninth-grade and twelfth-grade students as its subjects. 


\subsection{Instrumentation}

The instrument used in this study was a self-designed questionnaire with 40 questions or variables to measure two constructs: Form-focused Instruction (FFI) and Communication-focused Instruction (CFI). In order to achieve a high reliability, the questionnaire went through a double translation process and a pilot study. More specifically, the questionnaire was originally written in English and then translated into Chinese by the author. Then the author asked a Chinese friend with English proficiency to translate the Chinese questionnaire into English. The author compared the original questionnaire with the translated one (both in English) to check the missing information. For the original question which had a great difference with its translated one, the author went to check his Chinese translation and made some revisions. Last, the questionnaire in Chinese was used in a pilot study before it was administrated to the subjects.

\section{Results and Discussions}

\subsection{Demographic Data of the Study}

Table 1. The Sample of the Study

\begin{tabular}{lcccccc}
\hline & \multicolumn{2}{c}{ Grade } & \multicolumn{2}{c}{ Gender } & \multicolumn{2}{c}{ Ethnic } \\
\hline \multirow{3}{*}{ Number } & $9^{\text {th }}$ Grade & $12^{\text {th }}$ Grade & M & F & Han & Minority \\
\hline Percent & 300 & 300 & 300 & 300 & 527 & 73 \\
\hline
\end{tabular}

\subsection{Exploratory Factor Analysis}

In order to examine the construct validity of the questionnaire, a factor analysis was performed in this study. As a result, the loadings of 15 items or questions belonged to Factor 1 (CFI). The loadings of 14 items or questions were on Factor 2 (FFI). Accordingly, after factor analysis a total of 11 questions of the questionnaire were removed from data analysis. For the remained items, the highest factor loading reached .598 and the lowest factor loading was .342 . Two factors accounted for $23.74 \%$ of item variance.

Table 2. Factor Analysis on the Constructs of FFI and CFI

\begin{tabular}{llllll}
\hline Variables & Factor 1 & Factor 2 & Variables & Factor 1 & Factor 2 \\
\hline Question 6 & $.598^{*}$ & -.007 & Question 5 & -.035 & $.534^{*}$ \\
Question 8 & $.581^{*}$ & .018 & Question 13 & .026 & $.519^{*}$ \\
Question 16 & $.570^{*}$ & .089 & Question 1 & -.066 & $.490^{*}$ \\
Question 2 & $.568^{*}$ & -.118 & Question 3 & -.107 & $.470^{*}$ \\
Question 20 & $.513^{*}$ & .000 & Question 27 & -.202 & $.444^{*}$ \\
Question 4 & $.507^{*}$ & -.099 & Question 31 & .079 & $.432^{*}$ \\
Question 24 & $.490^{*}$ & .104 & Question 11 & .168 & $.429^{*}$ \\
Question 36 & $.486^{*}$ & -.006 & Question 35 & .023 & $.426^{*}$ \\
Question 18 & $.476^{*}$ & .059 & Question 19 & -.033 & $.412^{*}$ \\
Question 14 & $.476^{*}$ & -.156 & Question 29 & -.013 & $.397^{*}$ \\
Question 28 & $.446^{*}$ & .020 & Question 17 & .015 & $.392^{*}$ \\
Question 26 & $.443^{*}$ & -.093 & Question 9 & -.339 & $.386^{*}$ \\
Question 32 & $.426^{*}$ & -.053 & Question 25 & -.083 & $.367^{*}$ \\
Question 12 & $.404^{*}$ & .300 & Question 7 & .114 & $.342^{*}$ \\
Question 38 & $.401^{*}$ & .089 & & & \\
\hline Variance explained by each factor & $14.13 \%$ (factor 1) & $9.61 \%$ (factor 2) \\
\hline
\end{tabular}




\subsection{Internal Consistency Reliability of the Instrument}

The instrument reliability of this study was determined by computing internal consistency. The results in Table 3 indicated that those items with an item-total correlation less than .30 were removed. Then through item analysis, the alpha value for the subscale of FFI (14 Items) reached an acceptable level of .76, and the alpha value for the subscale of CFI (15 items) achieved a good level of .83.

Table 3. Instrument Reliability of the Study

\begin{tabular}{llllll}
\hline Items & $\begin{array}{l}\text { Corrected } \\
\text { Item-Total } \\
\text { Correlation }\end{array}$ & $\begin{array}{l}\text { Cronbach's } \\
\text { Alpha if Item } \\
\text { deleted }\end{array}$ & $\begin{array}{l}\text { Items } \\
\text { (Questions) }\end{array}$ & $\begin{array}{l}\text { Corrected } \\
\text { Item-Total } \\
\text { Correlation }\end{array}$ & $\begin{array}{l}\text { Cronbach's } \\
\text { Alpha if Item } \\
\text { deleted }\end{array}$ \\
\hline Question 1 & .4349 & .7415 & Question 2 & .5186 & .8115 \\
Question 3 & .4318 & .7413 & Question 4 & .4748 & .8144 \\
Question 5 & .4543 & .7391 & Question 6 & .5509 & .8091 \\
Question 7 & .3002 & .7566 & Question 8 & .5274 & .8108 \\
Question 9 & .3504 & .7498 & Question 12 & .3388 & .8226 \\
Question 11 & .3378 & .7509 & Question 14 & .3804 & .8213 \\
Question 13 & .4379 & .7417 & Question 16 & .5158 & .8121 \\
Question 17 & .3035 & .7541 & Question 18 & .4426 & .8164 \\
Question 19 & .3822 & .7467 & Question 20 & .4641 & .8149 \\
Question 25 & .3303 & .7531 & Question 24 & .4433 & .8164 \\
Question 27 & .4247 & .7422 & Question 26 & .4082 & .8187 \\
Question 29 & .3466 & .7501 & Question 28 & .4058 & .8187 \\
Question 31 & .3567 & .7491 & Question 32 & .3923 & .8196 \\
Question 35 & .3584 & .7488 & Question 36 & .4454 & .9161 \\
& & & Question 38 & .3795 & .8201 \\
\hline N of Cases $=600$ & $\mathrm{~N}$ of Items $=14$ & N of Cases =600 & $\mathrm{N}$ of Items = 15 \\
Alpha = .7613 & & Alpha=.8281 & \\
\hline
\end{tabular}

4. 4 Analyses of Research Questions

\subsubsection{Research Question 1}

Research Question 1 focused on the perceptions of ninth-grade and twelfth-grade students regarding FFI and CFI. Therefore, collected data of this study were analyzed for descriptive statistics. The findings were as follows:

1) For ninth graders, the means on the variable FFI was 3.3600 with a standard deviation of 49946 and the means on the variable CFI was 3.7987 with a standard deviation of .49533 . The results of this analysis showed that ninth graders preferred CFI to FFI. For twelfth graders, the means on the variable FFI was 3.1512 with a standard deviation of .51615 and the means on the variable CFI was 3.8824 with a standard deviation of .52141. Like ninth graders, the results of this analysis showed that twelfth graders preferred CFI to FFI.

2) For male students, the means on the variable FFI was 3.3598 with a standard deviation of .51180 and the means on the variable CFI was 3.8098 with a standard deviation of .50040. The results of this analysis showed that male students preferred CFI to FFI. For female students, the means on the variable FFI was 3.1514 with a standard deviation of .50406 and the means on the variable CFI was 3.8713 with a standard deviation of .51812 . Like male students, the results of this analysis showed that female students preferred CFI to FFI.

For the four variables (FFI, CFI, integrative motivation and instrumental motivation), the criteria used to evaluate their means were basically based on the study of Chen (2002, p.142). In analyzing a 5-point-Likert-scale questionnaire of English learning strategies, the criteria he provides to evaluate the means of each variable is that: 1) A mean score of 4.5-5 indicates "always"; A mean score of 3.5-4.4 indicates "usually"; A mean score of 2.5-3.4 indicates "generally"; A mean score of 1.5-2.4 shows "not often"; A mean score of 1.0-1.4 indicates "almost never". Since the mean score between 2.5 and 3.4 includes a range below and above the neutral point 3 of a 5-point Likert 
scale, the author of this study doesn't agree with Chen's criteria. For the research in students' attitudes and perceptions, the author of this study strongly suggests that the criteria be set as: A mean score of 4.5-5 indicates "highly positive"; A mean score of 3.5-4.4 indicates "very positive"; A mean score of 2.5-3.4 indicates "almost negative"; A mean score of 1.5-2.4 indicates "very negative"; A mean score of 1.0-1.4 indicates "highly negative".

Based on the means of each variable and the above criteria, both ninth-grade and twelfth-grade students were not very positive toward FFI, while both groups showed high positive perceptions toward CFI. Additionally, the perceptions of male and female students were not very positive toward FFI, while both groups held a high positive attitude toward CFI.

The findings on the variable FFI are not very consistent with the studies by Yu, Liu and Littlewood (1995) and Schulz (1996), whose results indicated that students valued grammar learning and thought that doing grammar exercises could help improve their English proficiency. Similarly, the subjects of Yang's (1999) case study agreed that learning grammar was essential for studying a foreign language. Just two years ago, the study conducted by Jean and Simard (2011) showed that both students and teachers perceived grammar instruction as necessary and effective. In contrast, the findings on CFI in this study well support the research by Savignon and Wang (2003), in which the surveyed subjects (both junior and senior middle school students) showed preferences for meaning-based instruction and disfavored grammar-based instruction. A recent empirical study by Yang (2012) also indicated that college business students held highly positive attitudes toward task-based language approach, which is communication-focused. For these mixed findings, Pazaver and Wang (2009) explain that although from similar cultural and educational backgrounds, the Asian students hold different perceptions toward form-focused instruction. This is because students' different perspectives were based on their previous English learning experiences, current academic needs, English proficiency and future career choices.

Traditionally, Chinese students put a high value on learning English grammar. Their attitude has changed in recent years probably as a result of the Open Door Policy carried out in China since 1978. With the rapid development of Chinese economy, students have more and more opportunities to communicate with English speaking people, so they are likely to think communication skills should be their priority in learning English.

Table 4. Descriptive Statistics for Instruction Variables

\begin{tabular}{|c|c|c|c|c|c|}
\hline & Grade & Gender & Mean & Std. Dev. & $\mathrm{N}$ \\
\hline \multirow{9}{*}{$\begin{array}{l}\text { Form-focused } \\
\text { Instruction }\end{array}$} & \multirow[t]{3}{*}{ Grade 9} & $\mathrm{M}$ & 3.4857 & .46923 & 150 \\
\hline & & $\mathrm{F}$ & 3.2343 & .49860 & 150 \\
\hline & & Total & 3.3600 & .49946 & 300 \\
\hline & \multirow[t]{3}{*}{ Grade 12} & M & 3.2338 & .52299 & 150 \\
\hline & & $\mathrm{F}$ & 3.0686 & .49742 & 150 \\
\hline & & Total & 3.1512 & .51615 & 300 \\
\hline & \multirow[t]{3}{*}{ Total } & $\mathrm{M}$ & 3.3598 & .51180 & 300 \\
\hline & & $\mathrm{F}$ & 3.1514 & .50406 & 300 \\
\hline & & Total & 3.2556 & .51812 & 600 \\
\hline \multirow{9}{*}{$\begin{array}{l}\text { Communication- } \\
\text { focused } \\
\text { Instruction }\end{array}$} & \multirow[t]{3}{*}{ Grade 9} & $\mathrm{M}$ & 3.7551 & .48077 & 150 \\
\hline & & $\mathrm{F}$ & 3.8422 & .50733 & 150 \\
\hline & & Total & 3.7987 & .49533 & 300 \\
\hline & \multirow[t]{3}{*}{ Grade 12} & $\mathrm{M}$ & 3.8644 & .51509 & 150 \\
\hline & & $\mathrm{F}$ & 3.9004 & .52877 & 150 \\
\hline & & Total & 3.8824 & .52141 & 300 \\
\hline & \multirow[t]{3}{*}{ Total } & $\mathrm{M}$ & 3.8098 & .50040 & 300 \\
\hline & & $\mathrm{F}$ & 3.8713 & .51812 & 300 \\
\hline & & Total & 3.8406 & .50984 & 600 \\
\hline
\end{tabular}




\subsubsection{Research Question 2}

Research Question 2 focused on the differences in the perceptions of ninth-grade and twelfth-grade students regarding FFI and CFI. In this study, the main effects and interaction effects were measured by performing two-way MANOVA analysis. The level of significance for the $\mathrm{F}$ test was set at .05 .

Table 5. Two-way MANOVA Multivariate Tests for Instruction Variables

\begin{tabular}{llcccc}
\hline Effect & & Value & F (2, 595) & Sig. & Partial Eta Squared \\
\hline Grade & Pillai's Trace & .046 & 14.681 & .000 & .046 \\
& Wilks' Lambda & .954 & 14.681 & .000 & .046 \\
& Hotelling's Trace & .048 & 14.681 & .000 & .046 \\
& Roy's Largest Root & .048 & 14.681 & .000 & .046 \\
Gender & Pillai's Trace & .045 & 13.841 & .000 & .045 \\
& Wilks' Lambda & .957 & 13.841 & .000 & .045 \\
& Hotelling's Trace & .046 & 13.841 & .000 & .045 \\
& Roy's Largest Root & .046 & 13.841 & .000 & .045 \\
\hline Grade*Gender & Pillai's Trace & .003 & .715 & .487 & .003 \\
& Wilks' Lambda & .997 & .715 & .487 & .003 \\
& Hotelling's Trace & .003 & .715 & .487 & .003 \\
& Roy's Largest Root & .003 & .715 & .487 & .003 \\
\hline
\end{tabular}

In Table 5, Two-way MANOVA Multivariate Tests were performed to ascertain the effect of grade and gender on the dependent variables FFI and CFI. The results of Wilks' $\Lambda$ revealed that the main effect for grade was significant, and the main effect for Gender was significant too. However, the grade by gender interaction effect was not significant in this study. Since grade has only two levels, Grade 9 and Grade 12; and gender only has two levels, boys and girls. The main effect associated with grade told us that ninth-graders and twelfth-graders differ significantly in their perceptions. The main effect associated with gender showed that male students and female students differ significantly in their perceptions as well. Nonetheless, female or male students didn't change their attitudes toward English instruction as time passed. In other words, both ninth-grade and twelfth-grade male students were not positive toward FFI, and both ninth-grade and twelfth-grade female students were very positive toward CFI.

Table 6. Two-way MANOVA Tests of Between-Subjects Effects for Instruction Variables

\begin{tabular}{lccccccc}
\hline Source & $\begin{array}{c}\text { Dependent } \\
\text { Variables }\end{array}$ & $\begin{array}{l}\text { Type III Sum of } \\
\text { Squares }\end{array}$ & df & $\begin{array}{l}\text { Mean } \\
\text { Square }\end{array}$ & F & Sig. & $\eta^{2}$ \\
\hline Grade & FFI & 6.54 & 1 & 6.54 & 26.433 & .000 & .042 \\
& CFI & 1.053 & 1 & 1.053 & 4.075 & .044 & .007 \\
Gender & FFI & 6.510 & 1 & 6.510 & 26.312 & .000 & .042 \\
& CFI & .568 & 1 & .568 & 2.200 & .139 & .004 \\
Grade*Gender & FFI & .279 & 1 & .279 & 1.126 & .289 & .002 \\
& CFI & .098 & 1 & .098 & .379 & .538 & .001 \\
\hline Error & FFI & 147.468 & 596 & .247 & & & \\
& CFI & 153.983 & 596 & .258 & & & \\
\hline
\end{tabular}

$* \mathrm{p}<.0 \overline{05}$

The results from Two-way MANOVA analysis in Table 6 revealed that between ninth-grade and twelfth-grade students there existed a significant difference in the means of FFI, $\mathrm{F}(1,596)=26.43, \mathrm{P}<.05$. From the results in Table 4, ninth-graders held more positive perceptions toward FFI than twelfth graders. The results in Table 6 also revealed that a significant difference existed in the means of CFI between ninth-grade and twelfth-grade students. 
Based on the results in Table 4, twelfth graders showed more positive perceptions toward CFI than ninth graders. This attitude was observed by Zeng (2004), who found that Chinese students with a high level of language development expressed a desire to focus on oral skills rather than on explicit grammar study. Also, the findings in Table 6 showed that a difference in the means of FFI between the male sample and female sample was statistically significant. According to the results in Table 4, male students held more positive perceptions regarding FFI than female students. However, between the two groups of male and female students there was no significant difference existing in the means of CFI, F $(1,596)=2.20, \mathrm{P}>.05$.

\subsubsection{Research Question 3}

Research Question 3 attempted to explore the correlation between students' academic achievement and the two variables of FFI and CFI. To achieve this goal, multiple linear regression analysis was performed with the Forward method in this study.

Table 7. Bivariate Correlations among Variables for Ninth Graders

\begin{tabular}{llll}
\hline & AA & FFI & CFI \\
\hline AA (Academic Achievement) & 1 & & \\
FFI & .062 & 1 & \\
\hline CFI & $.219^{*}$ & .041 & 1 \\
\hline
\end{tabular}

$* \mathrm{p}<.005$

The results in Table 7 showed that the two predictors of FFI and CFI had some correlations with ninth graders' academic achievement. However, the variable FFI showed the weakest linear relationship with ninth graders' academic achievement while the variable CFI had a relatively stronger relationship with ninth graders' academic achievement. This finding is very unexpected by the author because in China English papers cover a large portion of grammatical rules. Very often, students learn English grammar for testing. One explanation is that Chinese students have to learn grammar for getting a high score but they don't think learning grammar is necessary for their future career.

Table 8. Bivariate Correlations among Variables for Twelfth Graders

\begin{tabular}{llll}
\hline & AA & FFI & CFI \\
\hline AA (Academic Achievement) & 1 & & \\
FFI & .097 & 1 & \\
\hline CFI & .114 & $-.150^{*}$ & 1 \\
\hline
\end{tabular}

$* \mathrm{p}<.005$

The results in Table 8 showed that the two variables of FFI and CFI showed some correlation with twelfth graders' academic achievement. Nevertheless, FFI had the weakest linear relationship with twelfth graders' academic achievement. Accordingly, results suggested that the two predictors might foresee twelfth graders' academic achievement to some extent, but the relationship between the two variables and academic achievement was not strong enough to be significant.

\section{Conclusions}

As two different teaching approaches, FFI and CFI have their own pedagogical features. In L2 or foreign language teaching, it is impossible for EFL teachers to expect every student to prefer the two at the same time. However, having a better understanding of students' perceptions regarding these two approaches will help EFL teachers improve their language teaching effectively. From this empirical study the major findings include: 1) Both ninth-grade and twelfth-grade students were highly positive toward CFI. 2) Both ninth-grade and twelfth-grade students showed almost negative perceptions toward FFI, but ninth graders were more positive toward FFI than twelfth graders. 3) Both male and female students were highly positive toward CFI. However, Male students were more positive toward FFI than female students, but female students were more positive toward CFI. 4) From the results of multiple linear regression analysis, CFI had relatively stronger relationship with the academic achievement of ninth-grade and twelfth-grade students than FFI.

Based on the findings of this study, a few conclusions can be drawn as follows: 1) In Chinese context, English teachers are encouraged to apply the communicative approach to foster and develop secondary school students' 
communication skills. 2) The communicative language teaching is gaining more and more popularity, but teaching grammar to junior high school students and male students are certain to achieve effective results. There "is ample evidence to demonstrate the teaching of grammar works" (Ellis, 2006, p.102). 3) In actual English teaching practice, EFL teachers need to take into account that male and female students have different preferences. In a communicative class, the active role of female students will produce certain influence on male students' oral skills. In a form-focused class, EFL teachers need to make full use of the positive attitudes of male students. 4) Two different teaching approaches (FFI and CFI) have certain positive relationship with students' academic achievement. Although there is a mixture of perceptions regarding the inclusion of explicit grammar instruction in a CLT classroom (Wong \& Barrea-Marlys, 2012), a combination of these two approaches will be a good teaching practice (Azar, 2007; Fotos, 2005; Spada \& Lightbown, 2009). What EFL teachers need to consider is how and when to apply these two approaches in English classes. 5) Whatever approaches are implemented in EFL classes and whatever content is taught to EFL students, EFL English instruction should be based on students' attitudes and perceptions. If the gaps between EFL teachers' preferences for and students' perceptions toward English instruction get to close, the effectiveness of classroom teaching will help EFL students to achieve great success in English learning.

\section{References}

Azar, B. (2007). Grammar-based teaching: A practitioner's perspective. TESL-EJ, 11(2). Retrieved August 3, 2013 from http://tesl-ej.org/ej42/a1.html.

Canale, M., \& Swain, M. (1980). Theoretical bases of communicative approaches to second language teaching and testing. Applied Linguistics, 1(1), 1-47. http://dx.doi.org/10.1093/applin/1.1.1

Chen, X.T., \& Zheng, M. (2002). English learning strategies. Beijing: Foreign Language Teaching and Research Press.

Chomsky, N. (1965). Aspects of the theory of syntax. Cambridge: M.I.T. Press.

Eken, D. K. (1999). Through the eyes of the learner: Learner observations of teaching and learning. ELT Journal, 53(4). http://dx.doi.org/10.1093/elt/53.4.240

Ellis, R. (1994). The study of second language acquisition. Oxford: Oxford University Press.

Ellis, R. (2001). Introduction: Investigating form-focused instruction. In R. Ellis (Ed.), Form-focused instruction and second language learning (pp. 1-46). Oxford: Blackwell.

Ellis, R. (2006). Current issues in the teaching of grammar an SLA perspective. TESOL Quarterly, 40(1), 83-107. http://dx.doi.org/10.2307/40264512

Fotos, S. (2005). Traditional and grammar translation methods for second language teaching. In E. Hinkel (Ed.), Handbook of research in second language teaching and learning (pp. 653-670). Mahwah, NJ: Lawrence Erlbaum Associates.

Griego-Jones, T. (1994). Assessing students' perceptions of biliteracy in two way bilingual classrooms. The Journal of Educational Issues of Language Minority Students, 13, 79-93.

Harmer, J. (2007). The practice of English language teaching (4th ed.). London: Pearson Longman.

Horwitz, E. K. (1989). Facing the blackboard: Student perceptions of language learning and the

language classroom. ADFL Bulletin, 20 (3), 61-64. http://dx.doi.org/10.1632/adfl.20.3.61

Hymes, D. H. (1966). Two types of linguistic relativity. In W. Bright (Ed.), Sociolinguistics (pp.131-56). The Hague: Mouton.

Hymes, D. (1972). On communicative competence. In J. B. Pride \& J. Holmes (Eds.), Sociolinguistics (pp. 269-293). Harmondsworth: Penguin.

Jean, G., \& Simard, D. (2011). Grammar teaching and learning in L2: Necessary, but boring? Foreign Language Annals, 44(3), 467-494. http://dx.doi.org/10.1111/j.1944-9720.2011.01143.x

Larsen-Freeman, D., \& Long, M. H. (1991). An introduction to second language acquisition research. London/New York: Longman.

Laufer, B. (2006). Comparing focus on form and focus on formS in second-language vocabulary learning. Canadian Modern Language Review, 63, 149-166. http://dx.doi.org/10.3138/cmlr.63.1.149 
Long, M. H. (1983). Does second language instruction make a difference? A review of the research. TESOL Quarterly, 17, 359-382. http://dx.doi.org/10.2307/3586253

McCaslin, M.M., \& Good, T. L. (1996). Listening in classroom. Harper Collins College Publishers.

Norris, J. M., \& Ortega, L. (2000). Effectiveness of L2 instruction: A research synthesis and quantitative meta-analysis. Language Learning, 50(3), 417-528. http://dx.doi.org/10.1111/0023-8333.00136

Norris-Holt, J. (2002). An investigation of Japanese high school students' attitudes towards the study of English. Secondary Language Learning and Teaching (SLLT), 2,116-122. http://dx.doi.org/10.1111/0023-8333.00136

Nunan, D. (1988). The learner-centered curriculum. Cambridge, England: Cambridge University Press. http://dx.doi.org/10.1017/CBO9781139524506

Pazaver, A., \& Wang, H. (2009). Asian students' perceptions of grammar teaching in the ESL classroom. The International Journal of Language Society and Culture, 27, 27-35.

Richards, J. C., \& Nunan, D. (Eds.). (1990). Second language teacher education. Cambridge, England: Cambridge University Press.

Richards, J. C., \& Lockhart, C. (1994). Reflective teaching in second language classrooms. Cambridge, England: Cambridge University Press. http://dx.doi.org/10.1017/CBO9780511667169

Richards, J. C. (2006). Communicative language teaching today. Cambridge, England: Cambridge University Press.

Schulz, R.A. (1996). Focus on form in the foreign language classroom: Students' and teachers' views on error correction and the role of grammar. Foreign Language Annals, 29(3), 343-364. http://dx.doi.org/10.1111/j.1944-9720.1996.tb01247.x

Spada, N. (1997). Form-focused instruction and second language acquisition: A review of classroom and laboratory research. Language Teaching, 30, 73-87. http://dx.doi.org/10.1017/S0261444800012799

Spada, N., \& Lightbown, P. M. (2008). Form-focused instruction: Isolated or integrated? TESOL Quarterly, 42, 181-207.

Spada, N., \& Lightbown, P.M. (2009). Interaction research in second/foreign language classrooms. In A. Mackey \& P. Charlene (Eds.), Multiple perspectives on interaction (pp. 157-175). New York, NY: Routledge.

Savignon, S. J. (2002). Communicative competence: Theory and classroom practice (2nd ed.). New York: McGraw-Hill.

Savignon, S. J., \& Wang, C. (2003). Communicative language teaching in EFL contexts: Learner attitudes and perceptions. IRAL, 41(3), 223-49. http://dx.doi.org/10.1515/iral.2003.010

Tse, L. (2000). Student perceptions of language study: A qualitative analysis of foreign language autobiographies. The Modern Language Journal, 84 (1), 69-84. http://dx.doi.org/10.1111/0026-7902.00053

Walker, J. L. (1976). The student view: Attitudes toward foreign language learning. The ACTFL Foreign Language Education Series, 8.

Wong, C. C. Y., \& Barrea-Marlys, M. (2012). The role of grammar in communicative language teaching: An exploration of second language teachers' perceptions and classroom practices. Electronic Journal of Foreign Language Teaching, 9(1), 61-75.

Yang, Y. (1999). Reflection on English teaching and learning in China: A case study of two Chinese students in their first semester at Harvard. International Education, 28(20), 31-44.

Yang, Y. L. (2012). Business students' perceptions of tasks in Chinese tertiary level oral English classes. Asian ESP Journal, 8(3), 74-96.

Yu, C., Liu, N. F., \& Littlewood, W. (1995). How do secondary students perceive their English learning experience?--Report on a "Young Post" readers survey. Retrieved August 8, 2013 from http://www.hktalhk.edu.hk/hkta/NewHorizon/abstract/1996/page140.pdf

Zeng, M. (2004). The role of grammatical instruction within communicative language teaching among Chinese ESL students. Unpublished Master's thesis, University of Windsor, Windsor, Ontario, Canada. 